\title{
Mineralogical Compostion of Some Soils East of Kom Ombo City, Aswan Governorate, Egypt
}

\author{
M.M. Soliman", M.K. Abdel Ghaffar and A.D. Abdellatif \\ Soils, Water \& Environment Research Institute, ARC, Giza, \\ Egypt
}

\begin{abstract}
7 HE AIM of the current work is to identify the mineralogical composition of sand and clay fractions in order to evaluate the genesis and degree of homogeneity of soils in the study area.

Landsat ETM (Path 174/Row 43) image (2012) and digital elevation model (DEM) were used in ERDAS Imagine 9.2 software to produce the physiographic map of the study area. From the physiographic point of view, the landscapes include five units, i.e. sedimentary plain, low wadi plain, dissected erosion plain, terraces and wadi bottom. Ten soil profiles were selected to represent the main physiographic units. Morphological description was done and soil samples have been collected for physical and mineralogical analysis.
\end{abstract}

The data reveal that the sorting index $(\mathrm{So})$ of all soil profiles in the study area is poorly and very poorly sorted indicating aqueous media of transportation. The obtained data of skewness (Sk) reveal the symmetry of distribution towards coarse skewed throughout the majority of soil profile layers.

With regard to the mineralogical composition of these soils, the sand fraction consists of light and heavy minerals. The light minerals are the main constituents of sand fraction and consist mainly of quartz (> 90\%) followed by feldspars (plagioclase and orthoclase) in addition to muscovite and calcite minerals. On the other hand, the heavy minerals composed of opaques and non-opaques. Opaque minerals are generally the major heavy fraction constituents in all the examined soils. These minerals composed essentially of iron oxide minerals (e.g., magnetite, ilmenite and hematite). The complementary non-opaque minerals are recalculated to be as $100 \%$. These minerals consist of: (a) igneous origin minerals or unstable minerals (amphiboles, pyroxenes and epidotes); these minerals are mainly dominating the non-opaque minerals in the study area. (b) sedimentary origin minerals which are also named ultrastable or index minerals include zircon, rutile and tourmaline, these minerals are the second abundant minerals in the study area and, (c) metamorphic origin minerals or metastable minerals (garnet, kyanite, staurolite, silimanite and andalusite) are detected in considerable portions in the studied soils.

*E-mail:mahmoudaldemelawi@hotmail.com,mahmoudeldemelawi@yahoo.com 
The source rocks of the sand fraction in the study area are mixture of igneous, sedimentary and metamorphic rocks. The igneous rocks are the first source of sands in sediments of the study area. The vertical distribution of the uniformity ratios and weathering values are changed irregularly depthwise. This indicates that these sediments were inherited from multi-sources and/or may be subjected to different sedimentation cycles.

The abundance and distribution of amphiboles and pyroxenes minerals indicate that the studied soils are recent, poorly developed and immature from the pedogenic point of view. The soils units are mostly not affected by Nile sediments. The soils are weathered from the Red Sea igneous rocks and the sedimentary rocks of the surrounding area and transported by action of water during the wet period throughout the streams in the study area.

The data reveal that clay minerals suite is dominated by smectite, followed by kaolinite, while illite mineral is detected in few amounts. Furthermore, some non clay minerals, e.g., quartz, feldspars, calcite and dolomite are, however, detected in considerable amounts in some clay fractions.

It is well known that the clay minerals could be present as a result of inheritance from parent material by alteration, degradation of primary minerals, synthesizing and addition. Chemical decay is somewhat limited due to the prevalence of aridity, while the mechanical weathering contributes to a great extent. The variation in the relative content of the present clay minerals may be attributed mainly to sedimentation regime varieties and /or to the nature of the source rocks.

Keywords: Sand mineralogy, Clay mineralogy, Light and heavy minerals, Soil uniformity.

\section{Description of the studied area \\ Location}

The study area is located in the south eastern part of the Nile Valley, it extends from longitudes $33^{\circ}, 18^{-}, 11^{\circ}$ and $33^{\circ}, 26^{\circ}, 11^{\circ}$ East and latitudes $24^{\circ}$, $23^{-}, 30^{-}$and $24^{\circ}, 39^{-}, 10^{\circ}$ North. It covers parts of Aswan Governorate with a total area of 47331.8 feddans (Fig. 1).

Egypt. J. Soil Sci. 55, No. 2 (2015) 


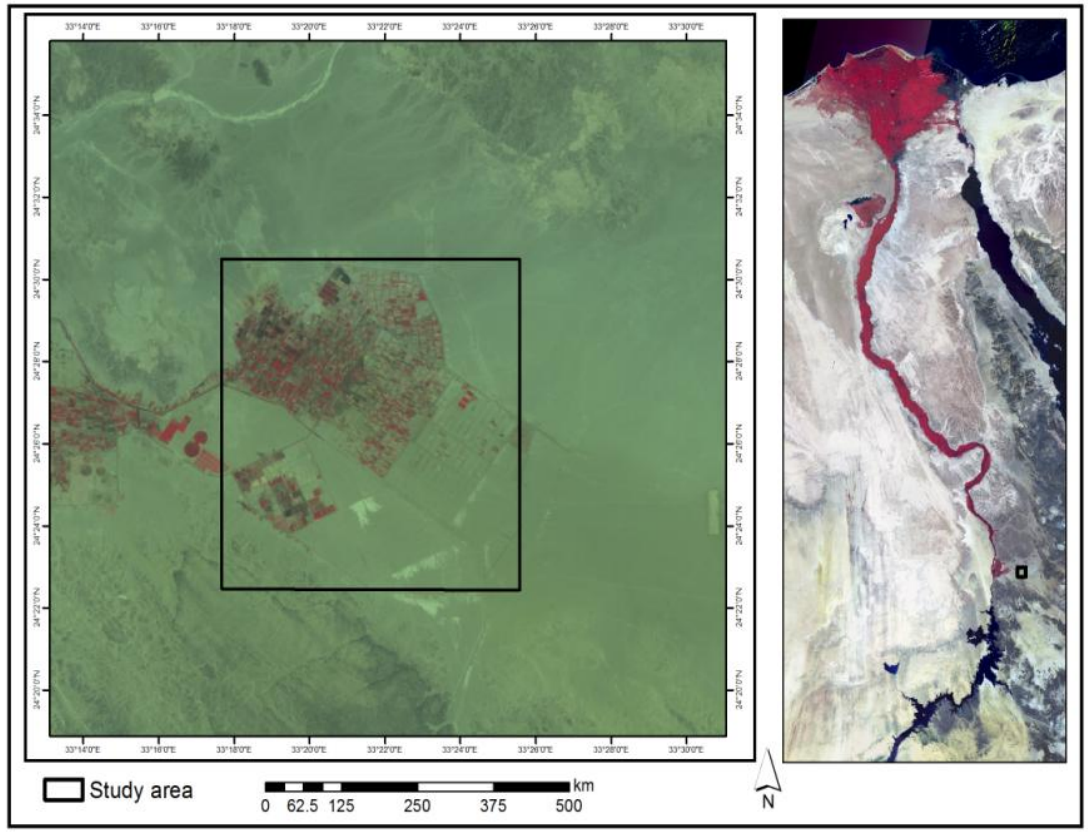

Fig. 1. Landsat ETM multispectral image (Bands 7, 4, 2) of the study area.

\section{Geology}

The investigated area is a part of the Pan African Arabian-Nubian Shield that was discussed by many workers (e.g., Said, 2000, Abo El- Ezz, 2000 and El Sayed et al., 2013). Proterozoic igneous and metamorphic and phanerozoic rocks are exposed within a geological map of the area illustrated in Fig. 2 from Egypt CONCO Coral map (1987). The study area is formed from the oldest to the youngest into the following succession:

1-Precambrian rocks are represented mainly by crystalline rocks of the basement complex.

2-The phanerozoic sedimentary cover is unconformably overlying the Precambrian basement (Fig. 2). It composed mainly of sandstones, siltstones, and shales, represented by the Abu Aggag, Timsah, Umm Brammily and Quseir formations of Upper Cretaceous age (El Sayed et al., 2013).

3-Quaternary deposits are represented by surficial accumulations of wadi deposits of clay, sands, gravels and rock fragments as well as sand sheets covering the low lands.

The aim of the current work is to identify the mineralogical composition of sand and clay fraction in order to evaluate the genesis and degree of homogeneity of soils in the study area. 


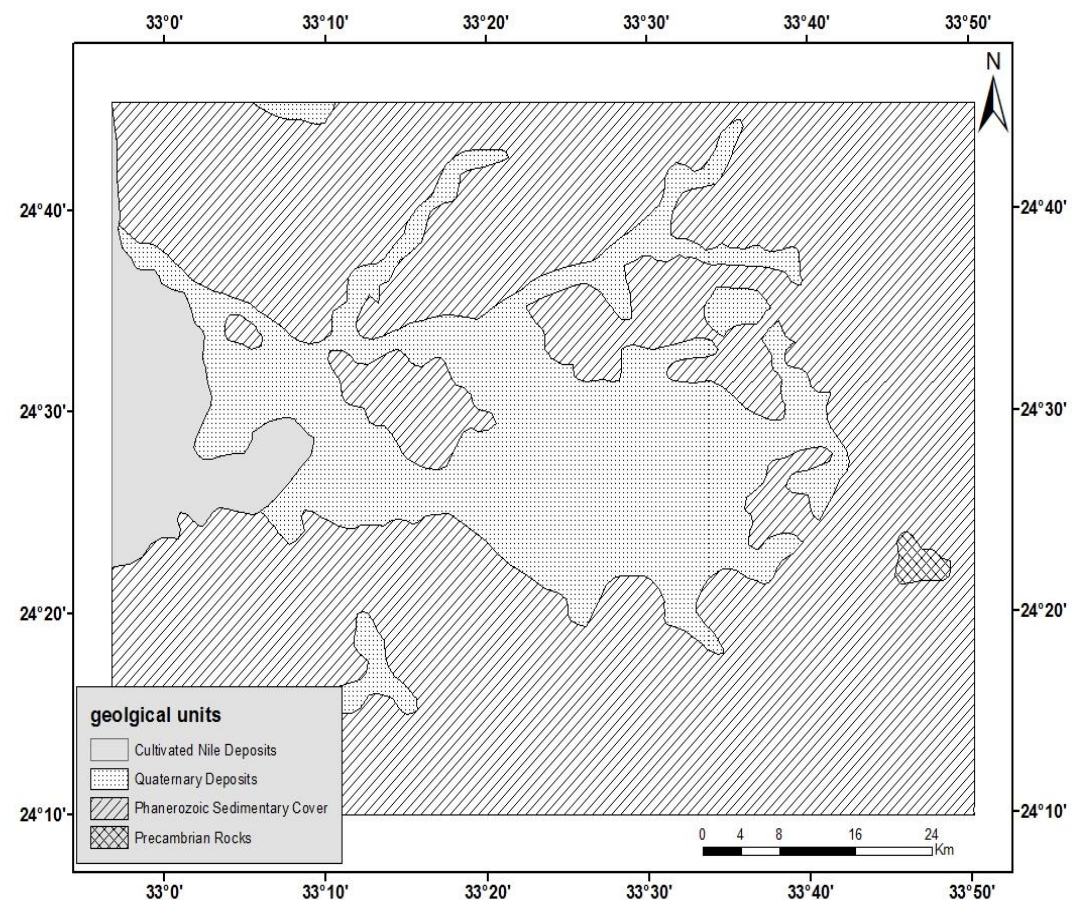

Fig. 2. Geological map of the study area (modified from Conoco Coral geological map, 1987).

\section{Materials and Methods}

1- Digital Elevation Model (DEM) of the study area has been generated from the vector contour lines and spot height extracted from topographic maps (scale 1:50000) by using Arc GIS 9.3 software.

2- Landsat ETM image (Path 174 / Row 43) taken during the year (2012) and digital elevation model (DEM) were used in ERDAS Imagine 9.2 software to produce the physiographic map of the study area according to Dobos et al. (2002).

3- Guided by the identified physiographic units; ten soil profiles were selected and allocated by the portable global positioning system (GPS) to represent the different physiographic units in the study area. Thirty five soil samples were collected from these soil profiles.

4- The grain size analysis was carried out using the methods of Folk (1980). The gravel contents ( $>2 \mathrm{~mm}$ diameter) were separated from the sample using 2 $\mathrm{mm}$ diameter screen. (Silt and clay were separated from sand by wet sieving using $0.063 \mathrm{~mm}$ diameter screen and determined by the pipette method.) Sand 
was fractionated by dry sieving using $2,1,0.5,0.25,0.125$ and $0.063 \mathrm{~mm}$ diameter screens.

5-Statistical size parameters: From the particle size distribution, data of cumulative frequency curves were graphically represented according to Pettijohn (1975). The sorting (So) and skewness (Sk) were calculated by using the following equations:

$$
\begin{aligned}
& \text { So }=(\mathrm{Q} 3 / \mathrm{Q} 1)^{1 / 2} \\
& \text { Sk }=\left(\mathrm{Q} 1 \mathrm{Q} 3 / \mathrm{Md}^{2}\right)^{1 / 2} \\
& \text { Where: } \\
& \text { Q1 }=\text { First quartile } \\
& \text { Q3 = Third quartile } \\
& \text { Md = Median }
\end{aligned}
$$

Q1, Q3 and Md were obtained from the cumulative curves. The relation between the degree of sorting and mode of deposition according to the scale of Pettijohn (1975) was used.

6- Separation of the light and heavy minerals was carried out by using bromoform (specific gravity $=2.85 \pm 0.02 \mathrm{~g} / \mathrm{cm}^{3}$ ) on the very fine sand fraction (0.125-0.063 $\mathrm{mm}$ in diameter) according to Brewer (1964). The separated light and heavy minerals were permanently mounted on glass slides using Canada balsam. Systematic identification of the minerals was carried out under the polarizing microscope as described by Keer (1959) and Milner (1962). About 500 grains in random fields were counted for each sample and the percentages of each mineral were calculated.

7-The mineralogical analysis of clay fraction $(<2 \mu)$ was carried out on ten representative soil samples to declare the clay mineral content of different physiographic units. Clay fraction $(<2 \mu)$ was separated by setting technique (Folk, 1980). The separated clay samples were slightly crushed and representative portion was disintegrated and dispersed by soaking in distilled water and stirring. The natural separated clay fraction was water precipitated onto glass slides to produce preferred orientation of the clay minerals. Oriented slides were prepared and examined as follows: Mg-saturated air dried, $\mathrm{Mg}$ saturated glycerol solvated, K- saturated air dried and K-saturated after heating to $550{ }^{\circ} \mathrm{C}$ for four hours.

The X-ray diffraction analysis (XRD) was carried out using Scintag, Inc., U.S.A, $\mathrm{X}_{1}$, Advanced Diffraction system with $\mathrm{Cu}$-radiation and $\mathrm{Ni}$ filter. The XRD data were interpreted using ASTM cards together with data published by Brindly and Brown (1980) and schemes adopted by Jackson (1965 \& 1969) and Dixon and Weed (1977). Semi-quantitative (relative proportions) of clay minerals identified were estimated by measuring the peak areas of the first order basal reflection (001) and calculating the percentages of frequency according to methods outlined by Weaver (1961), Biscays (1965), Gjems (1967) and Venkatarathnam \& Ryan (1971). 


\section{Results and Discussions}

Physiographic units of the study area

Physiographic units and profiles location are shown in Fig. 3 and some of the physical properties of the studied soils could be summarized as follows:

1-Sedimentary plain unit (profiles 1, 2 and 3): This unit is found in the north eastern part and south of the studied area, covering an area of about 18493.4 feddans, representing $39.1 \%$ of the whole area. The morphological description reveals that the soils of all representative profiles are very deep, more than 150 $\mathrm{cm}$, and most surfaces of these soils are flat to slightly undulating. The particle size distribution shows that textural classes of these soils varied from loamy sand to loam (Table 1).

2-Wadi plain (profile 4): This landform is located in the middle of the studied area, adjacent to Wadi bottom physiographic unit, and covering an area of about 7686.6 feddans, that represents $16.3 \%$. Topography of this unit ranged from almost flat to undulating and the surface is covered with desert pavement. Soil texture is loamy sand in the surface layer changed into sandy loam and loam in the deepest layers.

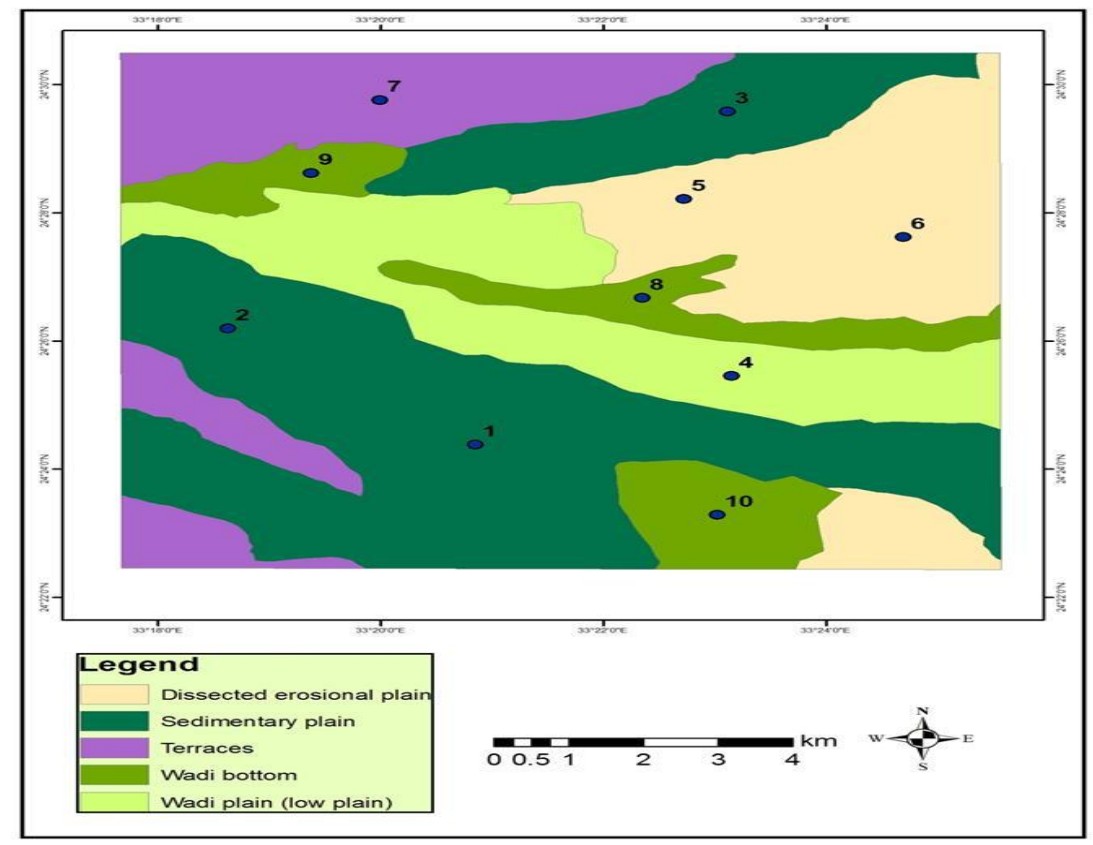

Fig. 3. Physiographic units and profiles location of the study area.

Egypt. J. Soil Sci. 55, No. 2 (2015) 
3-Dissected erosional plain unit (profiles 5 and 6): The soils of this mapping unit cover an area of about 8799.6 feddans (18.6\%) of the studied area. It is located in two parts, north of Wadi bottom and in the south eastern part of the studied area. Topography of this unit is undulating and the surface is covered with moderately fine to medium gravels. Data show that the soil texture ranges from sandy loam to clay.

4-Terraces unit (profile 7): This soil mapping unit occupies about 7217.6 feddans, (15.2\%). It is located in the north western part of the studied area. The surface is covered by desert pavements and few stones. Topography is undulating to sloping and the depth of this soil profile is more than $150 \mathrm{~cm}$ (very deep). Soil texture class is sandy loam throughout profile depths.

5-Wadi bottom unit (profiles 8, 9 and 10): This mapping unit is located in three parts of the studied area, in the middle, the south east and the north west. It occupies about 5134.5 feddans, $10.8 \%$ of the studied area. The surface of Wadi bottom is almost flat to gently undulating. Data show that, the depth of these soils ranges between 80 and $150 \mathrm{~cm}$ and soil texture ranges from sandy loam to clay loam.

\section{Statistical size parameters}

\section{1 -Sorting index}

The relationship between the degree of sorting and mode of deposition is worked out according to the scale of Pettijohn (1975). However, it is well known that sediments transported by wind are usually surveyed as well sorted, while those transported by water or weathered in situ are usually poorly sorted.

Accordingly, the data in Table 2 reveal that the sorting index ( $\mathrm{So}$ ) of all soil profiles in the study area is poorly and very poorly sorted, indicating aqueous media of transportation.

\section{2-Skewness coefficient}

The obtained data of skewness (Table 2) reveal the symmetry of distribution towards coarse skewed throughout the majority of soil profile layers except for profiles No. 3 and 10 which are fine skewed. The previous two patterns throughout soil profile layers mostly give evidence of partial dominance of fine fraction towards tails for the coarse skewed, while the reverse is true for the fine skewed. 
TABLE 1 Grain size distribution and texture classes of the studied soil samples.

\begin{tabular}{|c|c|c|c|c|c|c|c|c|}
\hline \multirow{2}{*}{$\begin{array}{c}\text { Prof. } \\
\text { No. }\end{array}$} & \multirow{2}{*}{$\begin{array}{c}\text { Depth, } \\
\text { cm }\end{array}$} & \multirow{2}{*}{$\begin{array}{c}\text { Gravel } \\
\%\end{array}$} & \multicolumn{4}{|c|}{ Particle size distribution \% } & \multirow{2}{*}{$\begin{array}{c}\text { Textural } \\
\text { Class }\end{array}$} & \multirow{2}{*}{$\begin{array}{c}\mathrm{CaCO}_{3} \\
\%\end{array}$} \\
\hline & & & C.S & F.S & Silt & clay & & \\
\hline \multicolumn{9}{|c|}{ Sedimentary plain } \\
\hline \multirow{4}{*}{1} & $0-20$ & 0.0 & 67.76 & 16.19 & 6.52 & 9.53 & LS & 2.20 \\
\hline & $20-50$ & 0.0 & 59.00 & 21.83 & 12.48 & 6.69 & $\mathrm{LS}$ & 3.14 \\
\hline & $50-100$ & 0.0 & 60.68 & 19.09 & 8.21 & 12.02 & SL & 5.32 \\
\hline & $100-150$ & 0.0 & 57.49 & 21.57 & 6.57 & 14.37 & SL & 6.10 \\
\hline \multirow{3}{*}{2} & $0-30$ & 0.0 & 61.17 & 14.86 & 6.76 & 17.21 & SL & 3.44 \\
\hline & $30-60$ & 0.0 & 58.32 & 18.87 & 8.81 & 14.00 & SL & 3.00 \\
\hline & $60-150$ & 0.0 & 51.96 & 20.11 & 19.46 & 8.47 & SL & 6.45 \\
\hline \multirow{3}{*}{3} & $0-30$ & 0.0 & 36.70 & 13.62 & 30.34 & 19.34 & $\mathrm{~L}$ & 6.05 \\
\hline & $30-60$ & 0.0 & 34.96 & 13.73 & 34.24 & 17.07 & $\mathrm{~L}$ & 5.10 \\
\hline & $60-150$ & 0.0 & 37.97 & 17.62 & 30.00 & 14.416 & SL & 11.35 \\
\hline \multicolumn{9}{|c|}{ Wadi plain (low plain) } \\
\hline \multirow{3}{*}{4} & $0-30$ & 0.0 & 65.04 & 16.38 & 8.09 & 10.49 & LS & 7.05 \\
\hline & $30-60$ & 0.0 & 51.47 & 17.89 & 31.32 & 14.32 & SL & 9.20 \\
\hline & $60-150$ & 0.0 & 36.06 & 12.90 & 29.22 & 20.82 & $\mathrm{~L}$ & 10.00 \\
\hline \multicolumn{9}{|c|}{ Dissected erosional plain } \\
\hline \multirow{3}{*}{5} & $0-20$ & 20 & 43.97 & 23.95 & 9.24 & 22.84 & SCL & 8.45 \\
\hline & $20-60$ & 0.0 & 30.01 & 20.35 & 31.42 & 18.22 & $\mathrm{~L}$ & 9.21 \\
\hline & $60-120$ & 0.0 & 32.22 & 15.88 & 32.40 & 19.50 & $\mathrm{~L}$ & 9.32 \\
\hline \multirow{4}{*}{6} & $0-10$ & 0.0 & 5.35 & 22.37 & 35.57 & 36.71 & $\mathrm{CL}$ & 8.84 \\
\hline & $10-40$ & 0.0 & 0.94 & 24.94 & 33.00 & 41.12 & $\mathrm{C}$ & 9.24 \\
\hline & $40-80$ & 0.0 & 1.22 & 27.79 & 32.50 & 38.49 & $\mathrm{C}$ & 8.64 \\
\hline & $80-120$ & 11 & 41.83 & 36.32 & 8.49 & 13.36 & SL & $\begin{array}{c}15.8 \\
7\end{array}$ \\
\hline \multicolumn{9}{|c|}{ Terraces } \\
\hline \multirow{4}{*}{7} & $0-10$ & 0.0 & 40.85 & 17.57 & 16.59 & 24.99 & SL & 10.10 \\
\hline & $10-20$ & 15 & 49.83 & 25.99 & 8.99 & 15.19 & SL & 5.24 \\
\hline & $20-60$ & 10 & 41.25 & 26.30 & 20.34 & 12.11 & SL & 6.20 \\
\hline & $60-150$ & 15 & 50.75 & 19.18 & 15.42 & 14.65 & SL & 6.30 \\
\hline \multicolumn{9}{|c|}{ Wadi bottom } \\
\hline \multirow{4}{*}{8} & $0-15$ & 0.0 & 4.99 & 23.48 & 40.25 & 31.28 & $\mathrm{CL}$ & 10.05 \\
\hline & $15-50$ & 0.0 & 0.52 & 23.88 & 47.50 & 28.10 & $\mathrm{CL}$ & 11.25 \\
\hline & $50-90$ & 0.0 & 0.69 & 23.81 & 40.32 & 35.18 & $\mathrm{CL}$ & 11.25 \\
\hline & $90-150$ & 0.0 & 1.02 & 17.01 & 48.10 & 33.87 & SiCL & 10.85 \\
\hline \multirow{4}{*}{9} & $0-15$ & 0.0 & 3.02 & 43.72 & 28.26 & 25.00 & SCL & 10.65 \\
\hline & $15-40$ & 0.0 & 1.49 & 25.99 & 40.93 & 31.59 & CL & 11.05 \\
\hline & $40-90$ & 0.0 & 2.61 & 16.89 & 52.30 & 28.20 & $\mathrm{CL}$ & 13.86 \\
\hline & $90-150$ & 0.0 & 2.74 & 15.46 & 46.49 & 35.31 & SiCL & 11.23 \\
\hline \multirow{3}{*}{10} & $0-15$ & 10 & 42.01 & 16.94 & 18.80 & 22.25 & SCL & $10 . .40$ \\
\hline & $15-50$ & 15 & 45.11 & 31.69 & 9.90 & 13.99 & SL & 4.10 \\
\hline & $50-80$ & 20 & 37.59 & 23.57 & 7.65 & 25.87 & SCL & 5.70 \\
\hline
\end{tabular}

Texture class:

LS: Loamy Sand

SCL: Sandy Clay Loam

CL: Clay Loam

S1: Sandy Loam

SiCL: Silty Clay Loam

L: Loamy

C: Clay

Egypt. J. Soil Sci. 55, No. 2 (2015) 
MINERALOGICAL COMPOSTION OF SOME SOILS EAST OF KOM OMBO... 139

TABLE 2. Some statistical size parameters of the studied soil profiles.

\begin{tabular}{|c|c|c|c|c|c|c|c|c|c|}
\hline $\begin{array}{l}\text { Prof. } \\
\text { No. }\end{array}$ & $\begin{array}{l}\text { Depth } \\
\text { (cm) }\end{array}$ & Q3 & Md & Q1 & So & So index & SK & $\begin{array}{l}\text { Log } \\
\text { Sk }\end{array}$ & $\begin{array}{c}\text { Log } \\
\text { SK } \\
\text { index }\end{array}$ \\
\hline \multirow{4}{*}{1} & $0-20$ & 650 & 250 & 50 & 3.61 & Poorly sorted & 0.52 & -0.28 & Coarse \\
\hline & $20-50$ & 520 & 160 & 32 & 4.03 & Poorly sorted & 0.65 & -0.19 & Coarse \\
\hline & $50-100$ & 580 & 180 & 25 & 4.82 & V.poorly & 0.45 & -0.35 & Coarse \\
\hline & $100-150$ & 480 & 140 & 27 & 4.22 & Poorly sorted & 0.66 & -0.18 & Coarse \\
\hline \multirow{3}{*}{2} & $0-30$ & 720 & 200 & 25 & 5.37 & V.poorly & 0.45 & -0.35 & Coarse \\
\hline & $30-60$ & 700 & 280 & 27 & 5.10 & V.poorly & 0.24 & -0.62 & Coarse \\
\hline & $60-150$ & 620 & 240 & 16 & 6.22 & V.poorly & 0.41 & -0.39 & Coarse \\
\hline \multirow{3}{*}{3} & $0-30$ & 430 & 25 & 3.3 & 11.41 & V.poorly & 1.51 & 0.18 & Fine \\
\hline & $30-60$ & 370 & 18 & 3.5 & 10.28 & V.poorly & 1.99 & 0.30 & Fine \\
\hline & $60-150$ & 350 & 35 & 4.5 & 8.82 & V.poorly & 1.13 & 0.05 & Fine \\
\hline \multirow{3}{*}{4} & $0-30$ & 700 & 380 & 50 & 3.74 & poorly & 0.49 & -0.31 & Coarse \\
\hline & $30-60$ & 350 & 45 & 4.5 & 8.82 & V.poorly & 0.88 & -0.05 & Coarse \\
\hline & $60-150$ & 450 & 45 & 2.5 & 13.42 & V.poorly & 0.75 & -0.21 & Coarse \\
\hline \multirow{3}{*}{5} & $0-20$ & 540 & 140 & 4 & 11.62 & V.poorly & 0.33 & -0.49 & Coarse \\
\hline & $20-60$ & 300 & 28 & 3.5 & 9.26 & V.poorly & 1.15 & 0.06 & Fine \\
\hline & $60-120$ & 350 & 18 & 3 & 10.80 & V.poorly & 1.80 & 0.26 & Fine \\
\hline \multirow{3}{*}{6} & $0-15$ & 500 & 75 & 4 & 11.18 & V.poorly & 0.59 & -0.23 & Coarse \\
\hline & $15-50$ & 580 & 150 & 24 & 4.92 & V.poorly & 0.78 & -0.11 & Coarse \\
\hline & $50-80$ & 500 & 120 & 25 & 4.47 & poorly & 0.93 & -0.03 & Coarse \\
\hline \multirow{4}{*}{7} & $0-10$ & 500 & 90 & 25 & 4.47 & poorly & 1.24 & 0.03 & Fine \\
\hline & $10-20$ & 600 & 190 & 26 & 4.80 & V.poorly & 0.66 & -0.18 & Coarse \\
\hline & $20-60$ & 480 & 110 & 23 & 4.56 & V.poorly & 0.95 & -0.02 & Coarse \\
\hline & $60-150$ & 640 & 220 & 9 & 8.43 & V.poorly & 0.34 & -0.47 & Coarse \\
\hline \multirow{4}{*}{8} & $0-15$ & 30 & 6 & - & 5.48 & V.poorly & 0.91 & -0.04 & Coarse \\
\hline & $15-50$ & 20 & 6 & - & 4.47 & V.poorly & 0.74 & -0.13 & Coarse \\
\hline & $50-90$ & 20 & 5 & - & 4.47 & poorly & 0.89 & -0.05 & Coarse \\
\hline & $90-150$ & 15 & 5 & - & 3.87 & poorly & 0.77 & -0.11 & Coarse \\
\hline \multirow{4}{*}{9} & $0-15$ & 65 & 17 & 2 & 5.70 & V.poorly & 1.95 & -0.17 & Coarse \\
\hline & $15-40$ & 27 & 6 & - & 5.20 & V.poorly & 0.87 & -0.06 & Coarse \\
\hline & $40-90$ & 17 & 52 & - & 4.12 & poorly & 0.08 & -1.10 & Coarse \\
\hline & $90-150$ & 15 & 4.6 & - & 3.87 & poorly & 0.84 & -0.8 & Coarse \\
\hline \multirow{4}{*}{10} & $0-10$ & 28 & 4.8 & - & 5.29 & V.poorly & 1.10 & 0.04 & Fine \\
\hline & $10-40$ & 23 & 3.8 & - & 4.79 & V.poorly & 1.26 & 0.10 & Fine \\
\hline & $40-80$ & 25 & 3.8 & - & 5.00 & V.poorly & 1.32 & 0.12 & Fine \\
\hline & $80-120$ & 500 & 130 & 25 & 4.47 & poorly & 0.86 & -0.07 & Coarse \\
\hline
\end{tabular}

Q1 = First quartile

Q3 = Third quartile

So $=$ Sorting

Md $=$ Median

$\mathrm{Sk}=$ Skewness

Mineralogy of the sand fraction

Tables 3 and 4 show the distribution of light and heavy minerals of the sand fraction in the soil profiles under consideration as well as their distribution throughout the entire depth of each profile.

1- Light minerals ( $\mathrm{Sp} . \mathrm{Gr}<2.85 \mathrm{~g} / \mathrm{cm}^{3}$ )

The light minerals (Table 3 ) consist mainly of quartz (> 92\%) followed by feldspars (plagioclase and orthoclase, from 1-4\%) in addition to muscovite (1$3 \%$ ) and calcite $(0-2 \%)$. The dominancy of quartz over other members of the

Egypt. J. Soil Sci. 55, No. 2 (2015) 
light minerals is mostly related to its resistance to weathering and the disintegration during the multicyclic processes of sedimentation. On the other hand, the presence of feldspars could be taken as an indication that weathering prevailed during soil formation was not so drastic to cause a complete decay of minerals susceptible to weathering.

\section{2-Heavy minerals ( $\mathrm{Sp} . \mathrm{Gr}>2.85 \mathrm{~g} / \mathrm{cm}^{3}$ )}

The heavy minerals could be used as a tool to evaluate the source rocks, soil profile uniformity, and the state of mineral weathering. The frequency distribution of the heavy minerals (opaques and non-opaques) will be discussed in the same order as given in Table 3.

A-Opaque minerals: Opaque minerals are generally the major heavy fraction constituent in all the examined soils (from 36.6 to $48.3 \%$; Table 4). These minerals composed essentially of iron oxide minerals (e.g. magnetite, ilimenite and hematite).

B-Non Opaque minerals: The complementary non-opaque minerals are recalculated to be $100 \%$ (Table 4). These minerals consist of:

1- Minerals of igneous origin: The igneous or unstable minerals (amphiboles, pyroxenes and epidotes) are mostly dominating the non-opaque minerals (range from 38.2 to $65.7 \%$ ). The high content of these minerals are present in terraces unit (range from 55.6 to 62.3\%) followed by dissected erosional plain unit (range from 47.8 to $65.7 \%$ ), while the lowest contents are present in wadi bottom unit (range from 38.2 to $44.5 \%$ ).

The abundance of amphiboles and pyroxenes in the study area indicates recent and poorly developed sediments that were derived mainly from igneous rocks especially the Red Sea mountain series.

2- Minerals of sedimentary origin: They are also named ultrastable or index minerals and include zircon, rutile and tourmaline minerals, among them zircon is the abundant index mineral in the study area. These minerals are the second abundance minerals in study area (range from 17.6 to $36.2 \%$ ). The high percent of these minerals are present in wadi bottom unit (range from 32.4 to $36.2 \%$ ) followed by wadi plain unit (range from 27.8 to 31.3 ), while the low percent are present in terraces unit (range from 17.6 to $24.2 \%$ ).

The occurrence of ultrastable minerals in the heavy suite means either (1) the minerals are being reworked from older sediments (Folk, 1968) or sedimentary rocks, e.g. the Nubian sandstone of the study area and/or (2) prolonged abrasion and/or chemical attach has occurred. The active physical and inactive chemical weathering processes on multi-sources parent materials lead to the prevalence of immature soil profiles in the study area. This is

Egypt. J. Soil Sci. 55, No. 2 (2015) 
MINERALOGICAL COMPOSTION OF SOME SOILS EAST OF KOM OMBO... 141 indicated by the irregular distribution of the ultrastable minerals in the different units and also by the irregular vertical distribution of such minerals depthwise.

TABLE 3. Frequency distributions of light minerals $(0.125-0.063 \mathrm{~mm})$ in different physiographic units.

\begin{tabular}{|c|c|c|c|c|c|}
\hline Profile No. & $\begin{array}{l}\text { Depth } \\
\text { (cm) }\end{array}$ & $\begin{array}{l}\text { Quartz } \\
\%\end{array}$ & $\begin{array}{l}\text { Feldspars } \\
\%\end{array}$ & $\begin{array}{l}\text { Muscovite } \\
\%\end{array}$ & Calcite \% \\
\hline \multicolumn{6}{|c|}{ Sedimentary plain } \\
\hline \multirow[t]{4}{*}{1} & $0-20$ & 94 & 2 & 3 & 1 \\
\hline & $20-50$ & 95 & 2 & 2 & 1 \\
\hline & $50-100$ & 94 & 3 & 2 & 1 \\
\hline & $100-150$ & 94 & 3 & 1 & 2 \\
\hline \multirow[t]{3}{*}{2} & 0-30 & 95 & 3 & 1 & 2 \\
\hline & $30-60$ & 95 & 2 & 2 & 1 \\
\hline & $60-150$ & 95 & 2 & 2 & 1 \\
\hline \multirow[t]{3}{*}{3} & $0-30$ & 94 & 1 & 3 & 2 \\
\hline & $30-60$ & 94 & 2 & 3 & 1 \\
\hline & $60-150$ & 94 & 2 & 2 & 2 \\
\hline \multicolumn{6}{|c|}{ Wadi plain (low plain) } \\
\hline \multirow[t]{3}{*}{4} & $0-30$ & 95 & 2 & 2 & 1 \\
\hline & $30-60$ & 96 & 2 & 3 & 0.0 \\
\hline & $60-150$ & 94 & 2 & 3 & 1 \\
\hline \multicolumn{6}{|c|}{ Dissected erosional plain } \\
\hline \multirow[t]{3}{*}{5} & $0-20$ & 93 & 3 & 2 & 2 \\
\hline & $20-60$ & 95 & 2 & 2 & 1 \\
\hline & $60-120$ & 94 & 3 & 2 & 1 \\
\hline \multirow[t]{3}{*}{6} & $0-15$ & 96 & 3 & 3 & 1 \\
\hline & $15-50$ & 95 & 2 & 2 & 1 \\
\hline & $50-80$ & 94 & 2 & 2 & 2 \\
\hline \multicolumn{6}{|c|}{ Terraces } \\
\hline \multirow[t]{4}{*}{7} & $0-10$ & 95 & 3 & 1 & 1 \\
\hline & $10-20$ & 96 & 2 & 2 & 0.0 \\
\hline & $20-60$ & 95 & 2 & 2 & 1 \\
\hline & $60-150$ & 95 & 3 & 2 & 0.0 \\
\hline \multicolumn{6}{|c|}{ Wadi bottom } \\
\hline \multirow[t]{4}{*}{8} & $0-15$ & 95 & 3 & 1 & 1.0 \\
\hline & $15-50$ & 94 & 3 & 1 & 2.0 \\
\hline & $50-90$ & 95 & 2 & 2 & 1.0 \\
\hline & $90-150$ & 93 & 3 & 3 & 1.0 \\
\hline \multirow[t]{4}{*}{9} & $0-15$ & 92 & 3 & 3 & 2.0 \\
\hline & $15-40$ & 93 & 3 & 2 & 2.0 \\
\hline & $40-90$ & 94 & 3 & 1 & 2.0 \\
\hline & $90-150$ & 94 & 3 & 1 & 2.0 \\
\hline \multirow[t]{3}{*}{10} & $0-15$ & 94 & 3 & 2 & 1.0 \\
\hline & $15-50$ & 93 & 3 & 2 & 2.0 \\
\hline & $50-80$ & 92 & 4 & 2 & 2.0 \\
\hline
\end{tabular}


TABLE 4. Frequency distributions of the heavy minerals in the recorded soil profiles of the study area.

\begin{tabular}{|c|c|c|c|c|c|c|c|c|c|c|c|c|c|c|c|c|c|c|}
\hline \multirow{3}{*}{$\begin{array}{c}\text { Profile } \\
\text { No. }\end{array}$} & \multirow{3}{*}{$\begin{array}{c}\text { Depth, } \\
\text { cm. }\end{array}$} & \multirow{3}{*}{$\begin{array}{c}\text { Opaque } \\
\%\end{array}$} & \multicolumn{16}{|c|}{ Non Opaque minerals as $100 \%$} \\
\hline & & & \multicolumn{4}{|c|}{ Sedimentary Minerals } & \multicolumn{4}{|c|}{ Igneous Minerals } & \multirow[b]{2}{*}{ B } & \multicolumn{6}{|c|}{ Metamorphic Minerals } & \multirow[t]{2}{*}{ Oth. } \\
\hline & & & $\mathbf{Z}$ & $\mathbf{R}$ & $\mathbf{T}$ & total & A & $\mathbf{P}$ & $\mathbf{E}$ & total & & Gr. & St. & Si. & An. & Ky. & total & \\
\hline \multicolumn{19}{|c|}{ Sedimentary plain } \\
\hline \multirow{4}{*}{1} & $0-20$ & 38.7 & 19.3 & 3.6 & 3.0 & 25.9 & 36.1 & 16.3 & \begin{tabular}{|l|}
1.2 \\
\end{tabular} & 53.6 & 7.8 & 1.8 & 2.4 & 2.4 & 3.0 & 1.8 & 11.4 & 1.3 \\
\hline & $20-50$ & 38.9 & 13.9 & 1.7 & 2.8 & 18.4 & 38.9 & 21.2 & 1.7 & 61.8 & 7.4 & 1.1 & 2.2 & 1.7 & 2.8 & 1.7 & 11.5 & 0.9 \\
\hline & $50-100$ & 38.2 & 12.4 & 1.0 & 4.4 & 17.8 & 34.6 & 22.8 & 4.4 & 61.8 & 6.4 & 2.0 & 3.0 & 2.5 & 2.5 & 1.5 & 11.5 & 2.5 \\
\hline & $100-150$ & 41.7 & 17.8 & 7.7 & 3.6 & 29.1 & 30.6 & 11.3 & 4.6 & 46.5 & 4.6 & 2.6 & 4.1 & 3.6 & 4.1 & 3.1 & 17.5 & 2.3 \\
\hline \multirow{3}{*}{2} & $0-30$ & 36.6 & 14.6 & 3.9 & 2.9 & 21.4 & 31.8 & 19.1 & 2.9 & 53.8 & 5.8 & 2.9 & 4.6 & 2.9 & 4.0 & 2.9 & 17.3 & 1.7 \\
\hline & $30-60$ & 39.6 & 16.4 & 4.4 & 2.7 & 23.5 & 31.7 & 20.7 & 1.6 & 54.0 & 3.3 & 2.7 & 4.4 & 3.8 & 4.4 & 2.7 & 18.0 & 1.2 \\
\hline & $60-150$ & 40.1 & 19.2 & 3.8 & 1.1 & 24.1 & 32.9 & 22.3 & 1.1 & 56.3 & 4.4 & 2.8 & 3.5 & 2.8 & 2.8 & 1.7 & 13.6 & 1.6 \\
\hline \multirow{3}{*}{3} & $0-30$ & 41.5 & 27.1 & 0.6 & 1.9 & 29.6 & 35.5 & \begin{tabular}{|l|}
17.4 \\
\end{tabular} & 0.6 & 53.5 & 3.2 & 2.6 & 2.6 & 1.9 & 3.2 & 1.9 & 12.2 & 1.5 \\
\hline & $30-60$ & 40.7 & 18.7 & 3.1 & 1.9 & 23.7 & 31.2 & 21.9 & 3.1 & 56.2 & 3.1 & 3.3 & 4.4 & 2.5 & 3.1 & 1.8 & 15.1 & 1.9 \\
\hline & $60-150$ & 40.7 & 23.7 & 4.3 & 3.1 & 31.1 & 33.1 & 15.6 & 4.4 & 53.1 & 1.9 & 3.1 & 2.5 & 1.9 & 3.1 & 1.9 & 12.5 & 1.4 \\
\hline \multicolumn{19}{|c|}{ Wadi plain (low plain) } \\
\hline \multirow[t]{3}{*}{4} & $0-30$ & 39.8 & 22.9 & 5.4 & 3.0 & 31.3 & 33.1 & 14.5 & 1.2 & 48.8 & 1.8 & 3.0 & 4.8 & 1.8 & 4.8 & 1.8 & 16.2 & 1.9 \\
\hline & $30-60$ & 38.5 & 19.9 & 5.8 & 4.0 & 29.7 & 33.0 & 14.2 & 3.4 & 50.6 & 5.7 & 2.7 & 2.8 & 2.8 & 3.1 & 1.1 & 12.5 & 1.5 \\
\hline & $60-150$ & 42.5 & 22.7 & 2.9 & 1.7 & 27.3 & 36.9 & 18.2 & 1.1 & 56.2 & 1.7 & 1.7 & 2.8 & 2.8 & 4.0 & 1.7 & 13.0 & 1.8 \\
\hline \multicolumn{19}{|c|}{ Dissected erosional plain } \\
\hline \multirow{3}{*}{5} & $0-20$ & 44.3 & 21.6 & 2.9 & 1.8 & 26.3 & 37.4 & 19.8 & \begin{tabular}{|l|l|}
0.0 \\
\end{tabular} & 57.2 & 1.8 & 2.9 & 2.9 & 1.8 & 4.1 & 1.8 & 13.5 & 1.2 \\
\hline & $20-60$ & 47.4 & 21.3 & 3.8 & 2.3 & 27.4 & 30.0 & 16.3 & 1.5 & 47.8 & 3.0 & 3.8 & 3.8 & 5.3 & 5.0 & 3.0 & 21.9 & 0.9 \\
\hline & $60-120$ & 45.4 & 20.5 & 4.0 & 1.6 & 26.1 & 35.3 & 17.2 & 1.1 & 53.6 & 2.8 & 3.1 & 3.2 & 2.5 & 5.5 & 2.7 & 17.0 & 0.5 \\
\hline & $0-15$ & 43.2 & 23.4 & 4.4 & 3.2 & 31.0 & 31.0 & 20.3 & 0.6 & 51.9 & 0.6 & 2.5 & 3.2 & 3.2 & 4.4 & 1.3 & 14.6 & 1.9 \\
\hline 6 & $15-50$ & 42.3 & 20.1 & 2.4 & 1.2 & 23.7 & 39.6 & 18.3 & 0.6 & 58.5 & 3.0 & 3.0 & 2.4 & 2.4 & 3.6 & 0.9 & 12.3 & 2.5 \\
\hline & $50-80$ & 42.5 & 22.2 & 4.0 & 2.3 & 28.5 & 36.9 & 18.7 & 1.1 & 65.7 & 2.3 & 2.3 & 2.3 & 2.3 & 2.8 & 1.8 & 11.5 & 1.0 \\
\hline & & & & & & & & Terrace & & & & & & & & & & \\
\hline & $0-10$ & 41.4 & 12.9 & 2.9 & 1.8 & 17.6 & 38.2 & 22.9 & 1.2 & 62.3 & 5.3 & 1.8 & 2.9 & 1.8 & 4.8 & 1.8 & 13.1 & 1.7 \\
\hline 7 & $10-20$ & 48.3 & 17.9 & 3.6 & 1.8 & 23.3 & 38.7 & 14.9 & 1.8 & 55.6 & 6.0 & 2.4 & 3.0 & 3.0 & 4.2 & 1.9 & 14.5 & 0.8 \\
\hline & $20-60$ & 46.4 & 18.2 & 3.5 & 1.6 & 23.3 & 39.4 & 15.4 & 1.5 & 56.3 & 5.2 & 1.8 & 2.4 & 2.6 & 3.9 & 2.7 & 13.4 & 1.8 \\
\hline & $60-150$ & 45.3 & 19.2 & 3.6 & 1.4 & 24.2 & 37.9 & 17.8 & 1.2 & 56.9 & 4.4 & 1.4 & 2.5 & 1.9 & 3.5 & 2.8 & 12.1 & 2.4 \\
\hline & & & & & & & & adi bot & ttom & & & & & & & & & \\
\hline & $0-15$ & 46.5 & 25.0 & 4.5 & 3.3 & 32.8 & \begin{tabular}{|l|}
31.9 \\
\end{tabular} & 17.3 & \begin{tabular}{|l|}
1.0 \\
\end{tabular} & 50.2 & 5.1 & 1.5 & 2.4 & 1.2 & 3.1 & 1.3 & 9.5 & 2.4 \\
\hline 8 & $15-50$ & 45.3 & 26.4 & 3.9 & 3.1 & 33.4 & 31.4 & 18.4 & 0.9 & 50.3 & 5.2 & 2.1 & 2.1 & 1.3 & 2.9 & 1.4 & 9.8 & 1.3 \\
\hline & $50-90$ & 44.2 & 27.3 & 5.4 & 3.5 & 36.2 & 29.8 & 17.9 & 0.5 & 48.2 & 4.8 & 1.8 & 2.3 & 1.2 & 2.8 & 1.2 & 9.3 & 1.5 \\
\hline & $90-150$ & 43.8 & 26.8 & 3.4 & 3.6 & 33.8 & 33.1 & 18.5 & 0.6 & 51.8 & 4.1 & 1.6 & 2.5 & 1.4 & 2.4 & 1.1 & 8.9 & 1.4 \\
\hline & $0-15$ & 45.7 & 24.6 & 5.1 & 3.5 & 33.2 & 31.8 & 18.3 & 1.2 & 51.3 & 4.0 & 1.4 & 2.1 & 1.5 & 2.6 & 1.7 & 9.3 & 2.2 \\
\hline 9 & $15-40$ & 45.9 & 25.4 & 3.9 & 3.1 & 32.4 & 31.9 & 18.6 & 1.1 & 51.6 & 3.8 & 1.3 & 2.4 & 2.1 & 2.5 & 1.5 & 9.4 & 2.8 \\
\hline & $40-90$ & 47.1 & 25.6 & 4.2 & 2.9 & 32.7 & 32.5 & 17.5 & 0.9 & 50.9 & 3.9 & 1.8 & 2.5 & 1.8 & 1.9 & 1.4 & 9.6 & 2.9 \\
\hline & $90-150$ & 46.7 & 26.1 & 4.5 & 3.0 & 33.6 & 30.8 & 19.1 & 0.8 & 50.7 & 4.1 & 1.6 & 2.6 & 1.7 & 2.4 & 1.2 & 9.5 & 2.1 \\
\hline & $0-15$ & 48.3 & 27.1 & 4.5 & 3.6 & 35.2 & 30.7 & 16.8 & 1.0 & 48.5 & 4.2 & 2.1 & 2.5 & 1.9 & 2.4 & 1.9 & 10.8 & 1.3 \\
\hline 10 & $15-50$ & 47.2 & 26.5 & 4.2 & 3.8 & 34.5 & 31.2 & 17.2 & 1.1 & 49.5 & 3.7 & 1.8 & 2.7 & 1.6 & 2.3 & 1.8 & 10.2 & 2.1 \\
\hline & $50-80$ & 47.1 & 26.1 & 4.7 & 3.7 & 34.5 & 30.7 & 16.1 & 1.2 & 48.0 & 3.9 & 1.9 & 2.6 & 1.7 & 2.0 & 1.6 & 10.8 & 2.8 \\
\hline $\mathrm{Z}: \mathrm{Zi}$ & & & & a. & & 1 s & & B: 1 & oti & & & $\theta$ & & ${ }^{\circ}$ & & & & \\
\hline$\therefore \mathrm{Ru}$ & & & & Py & re & & & Gr: C & Gar & & & $\mathrm{y}: \mathrm{k}$ & ran & & & & & \\
\hline T: Tou & Irmalin & & & Ep & ote & & & St: & Stau & rolit & & & & & & & & \\
\hline
\end{tabular}

3- Minerals of metamorphic origin: The metamorphic or metastable minerals (garnet, kyanite, staurolite, sillimanite and andalusite) are detected in considerable portions in the studied soils (range from 9.3 to 21.9\%). Dissected erosional plain unit has the highest percent (range from 12.3 to 21.9) followed by sedimentary plain unit (range from 11.5 to $18.0 \%$ ), while wadi bottom unit have the low content (from 9.3 to $10.8 \%$ ).

Egypt. J. Soil Sci. 55, No. 2 (2015) 
The metamorphic minerals, as their name implies, are derived mainly from the metamorphic rocks (e.g., shists, gneisses and metamorphosed argillaceous rocks).

\section{Origin of sands}

The difference and random fluctuation in the distribution of heavy minerals associations in the sand fractions are mainly attributed to variations in nature of source rocks and environment of deposition. The source rocks of sand in the study area are mixture of igneous, sedimentary and metamorphic rocks. The igneous rocks are the first source of sands especially in the terraces and erosional dissected plain units, while the sedimentary rocks are the second source of sands especially in the wadi bottom and wadi plain units.

\section{Uniformity of parent materials}

This is based on the assumption that certain minerals are most resistant to weathering during sedimentation development process (Brewer, 1964). Such minerals are termed as index minerals. Generally, there is an agreement to consider zircon, tourmaline and rutile as index minerals because of their resistance to weathering processes. In this respect, if the total percentages of the uniformity ratio (the ratio between any two of the index minerals) and weathering values (ratios of minerals are assessable to weathering / those of resistant to weathering) are constant throughout the entire depth of the profile, this might suggest one parent material dominancy and subjected to the same sedimentation cycle. On the other hand, a difference in such trend in the profile marks the existence of parent material heterogeneity and/or many sedimentation cycles.

In the current investigation, uniformity within the different profiles has been indicated by applying different parameters, i.e. uniformity ratios and weathering values (Barshad, 1964, El-Kady, 1970 and Mitchell, 1975).

The data of the current investigation (Table 6) note the followings:

1-The vertical distribution of the ratio between any two of the index minerals and weathering values in the soil sediments are changed irregularly depthwise. This indicates that these sediments were inherited from multisources and/or may be subjected to different sedimentation cycles.

2-The distribution of amphiboles, pyroxenes and ultrastable minerals (see Table 4) indicates that the studied soils are recent, poorly developed and immature from the pedogenic point of view.

\section{The relation between the studied soils and Nile deposits}

Pyroxenes and amphiboles are readily susceptible to weathering and decay, thus their frequencies give an indication of the presence of recent deposition characteristic to the Nile sediments. Moreover, Kholief et al. (1969), in their mineralogical studies of sand deposits in the Nile Delta cited a triangle for the comparison of relative frequencies of pyroxenes, amphiboles and epidotes and their distribution after recalculation to one hundred percent. The suggested area inside the triangle represented the mean Nile sediments. 
A comparison of relative frequencies of pyroxenes, epidotes and amphiboles recalculated to one hundred percent, for the studied profiles (Table 5 and Fig. 4) and the Nile sediments (after Kolief et al., 1969), illustrates that the studied soils are characterized by different values of the above three minerals, but it is quite clear that the soils of the studied units are mostly not affected by Nile sediments. The soils are weathered from the Red Sea igneous rocks and the sedimentary rocks of the surrounding area by water action during the wet period throughout the streams in the study area.

TABLE 5. Pyroxenes, Amphipoles and Epidotes relationship in the study area.

\begin{tabular}{|c|c|c|c|c|}
\hline Profile No. & $\begin{array}{c}\text { Depth } \\
\text { (cm) }\end{array}$ & $\begin{array}{l}\text { A } \\
\%\end{array}$ & $\begin{array}{l}\mathbf{P} \\
\%\end{array}$ & $\begin{array}{l}\mathbf{E} \\
\%\end{array}$ \\
\hline \multicolumn{5}{|c|}{ Sedimentary plain } \\
\hline 1 & $\begin{array}{c}0-20 \\
20-50 \\
50-100 \\
100-150\end{array}$ & $\begin{array}{l}67.4 \\
62.9 \\
56.0 \\
56.4\end{array}$ & $\begin{array}{l}30.4 \\
34.3 \\
36.9 \\
31.0\end{array}$ & $\begin{array}{c}2.2 \\
2.8 \\
7.1 \\
12.6\end{array}$ \\
\hline 2 & $\begin{array}{c}0-30 \\
30-60 \\
60-150\end{array}$ & $\begin{array}{l}59.1 \\
58.7 \\
58.4 \\
\end{array}$ & $\begin{array}{l}35.5 \\
38.3 \\
39.6 \\
\end{array}$ & $\begin{array}{l}5.4 \\
3.0 \\
2.0\end{array}$ \\
\hline 3 & $\begin{array}{c}0-30 \\
30-60 \\
60-150\end{array}$ & $\begin{array}{l}66.3 \\
55.5 \\
62.3 \\
\end{array}$ & $\begin{array}{l}32.5 \\
38.9 \\
29.4 \\
\end{array}$ & $\begin{array}{l}1.2 \\
5.6 \\
8.3\end{array}$ \\
\hline \multicolumn{5}{|c|}{ Wadi plain (low plain) } \\
\hline 4 & $\begin{array}{c}0-30 \\
30-60 \\
60-150 \\
\end{array}$ & $\begin{array}{l}67.8 \\
65.2 \\
65.7 \\
\end{array}$ & $\begin{array}{l}29.7 \\
28.1 \\
32.4 \\
\end{array}$ & $\begin{array}{l}2.5 \\
6.7 \\
1.9 \\
\end{array}$ \\
\hline \multicolumn{5}{|c|}{ Dissected erosional plain } \\
\hline 5 & $\begin{array}{c}0-20 \\
20-60 \\
60-120\end{array}$ & $\begin{array}{l}65.4 \\
62.8 \\
65.8\end{array}$ & $\begin{array}{l}34.6 \\
34.1 \\
32.1\end{array}$ & $\begin{array}{l}0.0 \\
3.1 \\
2.1\end{array}$ \\
\hline 6 & $\begin{array}{c}0-15 \\
15-50 \\
50-80\end{array}$ & $\begin{array}{l}59.7 \\
67.7 \\
65.1 \\
\end{array}$ & $\begin{array}{l}39.1 \\
31.3 \\
33.0 \\
\end{array}$ & $\begin{array}{l}1.2 \\
1.0 \\
1.9\end{array}$ \\
\hline \multicolumn{5}{|c|}{ Terraces } \\
\hline 7 & $\begin{array}{c}0-10 \\
10-20 \\
20-60 \\
60-150 \\
\end{array}$ & $\begin{array}{l}61.3 \\
69.8 \\
70.0 \\
66.6 \\
\end{array}$ & $\begin{array}{l}36.7 \\
26.9 \\
27.3 \\
31.3 \\
\end{array}$ & $\begin{array}{l}2.0 \\
3.3 \\
2.7 \\
2.1 \\
\end{array}$ \\
\hline \multicolumn{5}{|c|}{ Wadi bottom } \\
\hline 8 & $\begin{array}{c}0-15 \\
15-50 \\
50-90 \\
90-150\end{array}$ & $\begin{array}{l}63.5 \\
62.4 \\
61.8 \\
63.9 \\
\end{array}$ & $\begin{array}{l}34.4 \\
36.5 \\
37.1 \\
35.7\end{array}$ & $\begin{array}{l}2.1 \\
1.1 \\
2.1 \\
1.4\end{array}$ \\
\hline 9 & $\begin{array}{c}0-15 \\
15-40 \\
40-90 \\
90-150\end{array}$ & $\begin{array}{l}62.0 \\
61.8 \\
63.8 \\
60.7\end{array}$ & $\begin{array}{l}35.6 \\
36.0 \\
34.4 \\
37.7\end{array}$ & $\begin{array}{l}2.4 \\
2.2 \\
1.8 \\
1.6\end{array}$ \\
\hline 10 & $\begin{array}{c}0-15 \\
15-50 \\
50-80\end{array}$ & $\begin{array}{l}63.3 \\
63.0 \\
64.0\end{array}$ & $\begin{array}{l}34.6 \\
34.7 \\
33.5\end{array}$ & $\begin{array}{l}2.1 \\
2.3 \\
2.5\end{array}$ \\
\hline
\end{tabular}

A=Amphiboles $\quad \mathrm{P}=$ Pyroxenes $\quad \mathrm{E}=$ Epidote

Egypt. J. Soil Sci. 55, No. 2 (2015) 


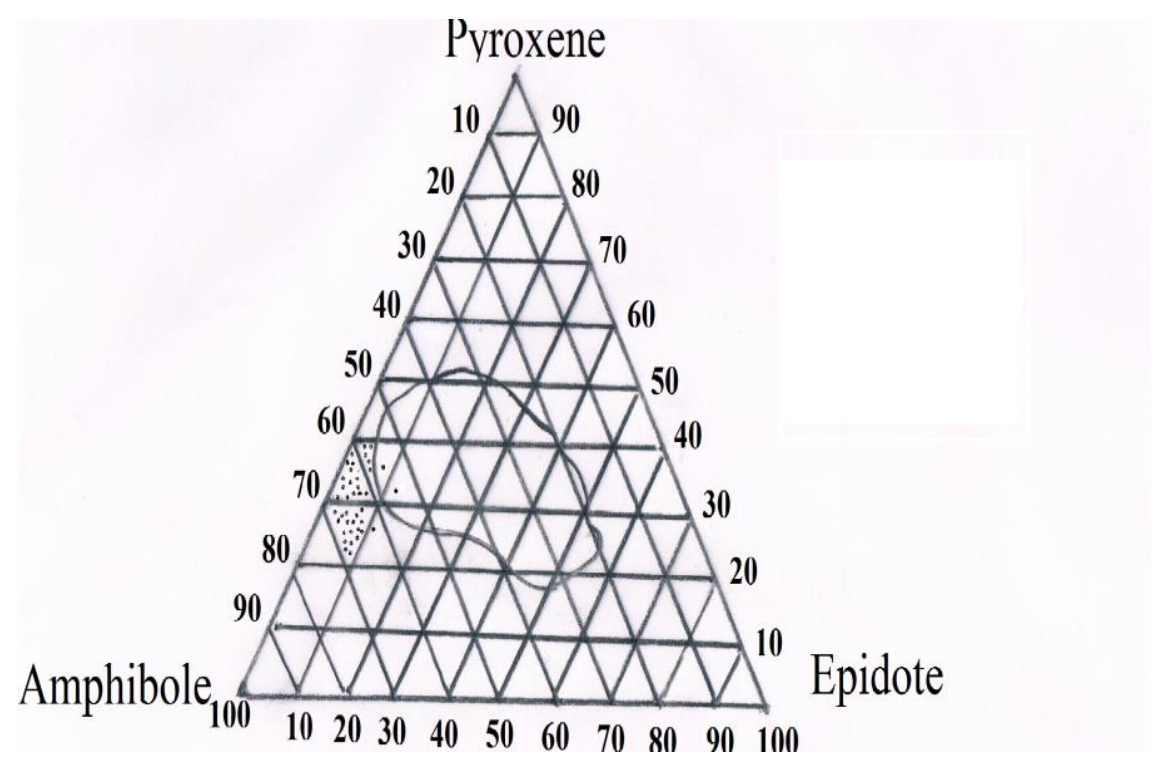

Fig. 4. Distribution of amphipoles, pyroxenes and epidote minerals in the study area.

Area of distribution of amphiboles, pyroxenes and epidotes minerals in the main Nile sediments (Kholief et al. , 1969)

Clay mineralogy

The clay fraction content of the soil is quite important in the field of agriculture land use. It constitutes the most active part in soil as well as controls the majority of the physical and chemical properties. Therefore, studying the mineralogical composition of the clay fraction is of vital importance to throw light on the nature and types of clay minerals which strongly affect the soil fertility and development.

\section{Identification of clay minerals}

Clay minerals identification in the present study is essentially based upon the X-ray diffraction analysis (XRD) of the clay fraction and their response to glycerol and heating to $550{ }^{\circ} \mathrm{C}$ treatments.

\section{$X$-ray diffraction analysis}

The XRD data are illustrated in Fig. 5-9 and summarized in Table 7. The data reveal that the clay mineral suite is dominated by smectite mineral throughout the studied soil profiles followed by kaolinite, while illite is detected in few amounts. Furthermore, some non clay minerals, e.g., quartz, feldspars, calcite and dolomite are detected in considerable amounts in some clay fractions. Identification of clay minerals is established as follows: 
TABLE 6.Uniformity and weathering ratios of the studied soil profiles.

\begin{tabular}{|c|c|c|c|c|c|c|c|}
\hline \multirow{2}{*}{$\begin{array}{l}\text { Profile } \\
\text { No. }\end{array}$} & \multirow{2}{*}{$\begin{array}{l}\text { Depth } \\
\text { (cm) }\end{array}$} & \multicolumn{3}{|c|}{ Uniformity ratios } & \multicolumn{3}{|c|}{ Weathering values } \\
\hline & & $\mathbf{Z r} / \mathbf{T}$ & $\mathbf{Z r} / \mathbf{R}$ & $\mathrm{Zr} / \mathrm{R}+\mathrm{T}$ & $\begin{array}{c}\text { Wr1 } \\
(\mathbf{P}+\mathbf{A} / \\
\mathrm{Zr}+\mathbf{T})\end{array}$ & $\begin{array}{c}\text { Wr2 } \\
(\mathrm{A} / \mathrm{Zr}+\mathrm{T})\end{array}$ & $\begin{array}{c}\text { Wr3 } \\
(\mathrm{B} / \mathrm{Zr}+\mathrm{T})\end{array}$ \\
\hline \multicolumn{8}{|c|}{ Sedimentary plain } \\
\hline \multirow[t]{4}{*}{1} & $0-20$ & 6.4 & 5.3 & 2.9 & 2.3 & 1.6 & 0.4 \\
\hline & $20-50$ & 5.0 & 8.4 & 3.1 & 3.6 & 2.3 & 0.2 \\
\hline & $50-100$ & 2.8 & 12.5 & 2.3 & 3.4 & 2.0 & 0.4 \\
\hline & $\begin{array}{c}100- \\
150 \\
\end{array}$ & 7.6 & 3.6 & 2.5 & 1.0 & 0.7 & 0.2 \\
\hline \multirow[t]{3}{*}{2} & $0-30$ & 3.7 & 3.7 & 1.8 & 3.7 & 2.3 & 0.4 \\
\hline & $30-60$ & 6.0 & 3.8 & 2.3 & 2.8 & 1.7 & 0.2 \\
\hline & $60-150$ & 14.5 & 5.8 & 4.2 & 3.2 & 1.9 & 0.5 \\
\hline \multirow[t]{3}{*}{3} & $0-30$ & 14.0 & 3.3 & 10.5 & 1.8 & 1.2 & 0.1 \\
\hline & $30-60$ & 10.0 & 6.0 & 3.4 & 2.6 & 1.5 & 0.1 \\
\hline & $60-150$ & 7.6 & 5.4 & 3.2 & 1.8 & 1.2 & 0.7 \\
\hline \multicolumn{8}{|c|}{ Wadi plain (low plain) } \\
\hline \multirow[t]{3}{*}{4} & $0-30$ & 7.6 & 4.2 & 2.7 & 1.5 & 1.3 & 0.7 \\
\hline & $30-60$ & 5.0 & 3.5 & 6.0 & 2.0 & 1.4 & 0.2 \\
\hline & $60-150$ & 13.0 & 7.9 & 5.0 & 2.3 & 1.5 & 0.1 \\
\hline \multicolumn{8}{|c|}{ Dissected erosional plain } \\
\hline \multirow[t]{3}{*}{5} & $0-20$ & 12.4 & 7.4 & 4.7 & 2.5 & 1.6 & 0.1 \\
\hline & $20-60$ & 13.0 & 8.0 & 4.9 & 1.2 & 0.3 & 0.1 \\
\hline & $60-120$ & 9.7 & 5.6 & 3.5 & 2.3 & 1.5 & 0.1 \\
\hline \multirow[t]{3}{*}{6} & $0-15$ & 7.4 & 5.1 & 3.1 & 1.9 & 1.2 & 0.0 \\
\hline & $15-50$ & 16.3 & 8.2 & 5.5 & 2.7 & 1.8 & 0.2 \\
\hline & $50-80$ & 9.8 & 5.8 & 3.5 & 2.2 & 1.5 & 0.1 \\
\hline \multicolumn{8}{|c|}{ Terraces } \\
\hline \multirow[t]{4}{*}{7} & $0-10$ & 6.9 & 4.4 & 2.8 & 4.2 & 2.6 & 0.4 \\
\hline & $10-20$ & 10.0 & 5.0 & 3.3 & 3.2 & 2.0 & 0.3 \\
\hline & $20-60$ & 11.4 & 5.2 & 3.6 & 2.8 & 2.0 & 0.3 \\
\hline & $60-150$ & 13.7 & 5.3 & 3.8 & 2.7 & 1.8 & 0.2 \\
\hline \multicolumn{8}{|c|}{ Wadi bottom } \\
\hline \multirow[t]{4}{*}{8} & $0-15$ & 7.6 & 4.5 & 3.2 & 1.7 & 1.1 & 0.2 \\
\hline & $15-50$ & 8.5 & 6.7 & 3.8 & 1.7 & 1.0 & 0.2 \\
\hline & $50-90$ & 7.8 & 5.0 & 3.1 & 1.5 & 1.0 & 0.2 \\
\hline & $90-150$ & 7.4 & 7.9 & 3.8 & 1.7 & 1.1 & 0.1 \\
\hline \multirow[t]{4}{*}{9} & $0-15$ & 7.0 & 4.8 & 2.8 & 1.8 & 1.1 & 0.1 \\
\hline & $15-40$ & 8.1 & 6.5 & 3.6 & 1.8 & 1.1 & 0.1 \\
\hline & $40-90$ & 8.8 & 6.1 & 3.6 & 1.7 & 1.1 & 0.1 \\
\hline & $90-150$ & 8.7 & 5.8 & 3.5 & 1.7 & 1.0 & 0.1 \\
\hline \multirow[t]{3}{*}{10} & $0-15$ & 7.5 & 6.0 & 3.3 & 1.5 & 1.0 & 0.1 \\
\hline & $15-50$ & 7.0 & 6.3 & 3.3 & 1.6 & 1.0 & 0.1 \\
\hline & $50-80$ & 7.0 & 5.5 & 3.1 & 1.6 & 1.0 & 0.1 \\
\hline Zircon & & $\mathrm{A}: \mathrm{A}$ & iibole & & & & \\
\hline R: Rutile & & P: Py & enes & & & & \\
\hline
\end{tabular}

Egypt. J. Soil Sci. 55, No. 2 (2015) 
MINERALOGICAL COMPOSTION OF SOME SOILS EAST OF KOM OMBO.

TABLE 7. Semi-quantitative mineralogical composition of the clay fractions separated from some layers of the representative profiles.

\begin{tabular}{|c|c|c|c|c|c|}
\hline $\begin{array}{c}\text { Profile } \\
\text { No. }\end{array}$ & $\begin{array}{c}\text { Depth, } \\
\text { cm }\end{array}$ & Smectite & Kaolinite & Illite & $\begin{array}{l}\text { Non clay } \\
\text { minerals }\end{array}$ \\
\hline \multirow{2}{*}{1} & $60-100$ & Dominant & Dominant & Few & \multirow{6}{*}{$\begin{array}{c}\text { Quartz, calcite, } \\
\text { feldspar and } \\
\text { dolomite }\end{array}$} \\
\hline & $100-150$ & Dominant & Dominant & Few & \\
\hline 2 & $\begin{array}{c}30-90 \\
90-150\end{array}$ & $\begin{array}{l}\text { Dominant } \\
\text { Dominant }\end{array}$ & $\begin{array}{l}\text { Dominant } \\
\text { Dominant }\end{array}$ & $\begin{array}{l}\text { Few } \\
\text { Few }\end{array}$ & \\
\hline 3 & $\begin{array}{c}30-60 \\
60-150\end{array}$ & $\begin{array}{l}\text { Dominant } \\
\text { Dominant }\end{array}$ & $\begin{array}{l}\text { Moderate } \\
\text { Dominant }\end{array}$ & $\begin{array}{l}\text { Few } \\
\text { Few }\end{array}$ & \\
\hline 4 & $\begin{array}{c}30-60 \\
60-150\end{array}$ & $\begin{array}{l}\text { Dominant } \\
\text { Dominant }\end{array}$ & $\begin{array}{l}\text { Moderate } \\
\text { Dominant }\end{array}$ & $\begin{array}{l}\text { Few } \\
\text { Few }\end{array}$ & \\
\hline 6 & $\begin{array}{l}15-50 \\
50-80\end{array}$ & $\begin{array}{l}\text { Dominant } \\
\text { Dominant }\end{array}$ & $\begin{array}{l}\text { Moderate } \\
\text { Moderate }\end{array}$ & $\begin{array}{l}\text { Few } \\
\text { Few }\end{array}$ & \\
\hline
\end{tabular}

Dominant (40-60\%) $\quad$ Moderate (21-39\%) $\quad$ Few (10-20\%)

\section{1-Smectite}

The XRD patterns of the representative clay samples show that smectite is the dominant clay minerals in most soil sediments. It exhibits a characteristic basal reflection (001) at about $14-15 \mathrm{~A}^{\mathrm{o}}$ for air-dried samples. Regarding the glycerol treatment, the characteristic peak of smectite expanded to about 17.6$18.0 \mathrm{~A}^{\circ}$. Heat treatment $\left(550^{\circ} \mathrm{C}\right.$ for four hours) collapses the hydrated layer to about $10 \mathrm{~A}^{\mathrm{o}}$ (Fig.5-9).

\section{2-Kaolinite}

Kaolinite is identified with relatively lower frequency than smectite in some of the studied clays. It exhibits two distinguished peaks at about 7.2 and $3.5 \mathrm{~A}^{\circ}$, which represent the first and second order basal reflections, respectively. The position of the two peaks is not affected by glycerol treatment, but the peaks completely disappeared as a result of kaolinite structure collapse when heated at $550{ }^{\circ} \mathrm{C}$ for four hr.

\section{3-Illite}

Illite is reported with lesser amounts than the former clay minerals. It is characterized by a series of weak, broad x-ray diffraction peaks at more or less $10.0 \mathrm{~A}^{\circ}(001)$ and $3.3 \mathrm{~A}^{\circ}(003)$. Neither glycolation nor heat treatments appreciably affect the peaks position.

\section{4- Non clay minerals}

The characteristic peaks of the other non-clay minerals are as follows: quartz $4.26 \& 3.34 \mathrm{~A}^{\mathrm{o}}$, feldspars 3.12 to $3.26 \mathrm{~A}^{\mathrm{o}}$, calcite $3.04 \mathrm{~A}^{\circ}$ and dolomite $2.28 \mathrm{~A}^{0}$. 
Origin and genesis of clay minerals

The clay minerals are not the same in both the chemical and structure compositions as they were formed by several ways. Keller (1965 and 1970) pointed out that the clay minerals may be considered fundamentally as a product of both the parent materials and the environments. The distribution and genesis of the recognized clay minerals can be discussed as follows:

1-Smectite suggested to be derived from volcanic source rocks of Red Sea basement rocks under arid climatic conditions where evaporation exceeds rainfall precipitation and leaching process is limited and in turn the alkaline conditions are prevailing. This finding is similar to the conclusion of Greensmith (1985).

2-Kaolinite may be formed in source areas by hydrogenation (decomposition) or by selective leaching of alkali feldspars under well aerated conditions and abundant rainfalls (Grim, 1968 and Millot, 1970). The considerable well crystalline kaolinite may also indicate a prolonged intensively weathered product in the source area.

3-Illite is a common detrital mineral inherited from very numerous sediments (Weaver, 1989). The majority of illite in the investigated soils is inherited in a degraded state from muscovite rich sedimentary rocks in the source area.

Further, the genesis of exised non-clay minerals can be briefed as follows

1- Quartz is inherited mostly from parent materials and transported to the basins of deposition either by streams or wind.

2- Feldspars may be derived from slightly weathered soil developed from highly feldspathic parent materials in the source area. It is worth to mention that the presence of feldspars may support the suggestion of immaturity poorly developed and relatively young age of the studied soils.

3- Calcite and dolomite may be inherited from the limestone parent material in immature soil profiles developed on young geomorphic surfaces. In conclusion, it is well known that the clay minerals could be present as a result of inheritance from parent material by alteration, degradation of primary minerals, synthesizing and addition. For the present study, the chemical decay is somewhat limited due to the prevalence of aridity, while the mechanical weathering contributes to a great extent. The variation in the relative content of the present clay minerals may be attributed mainly to sedimentation regime varieties and /or to the nature of the source rocks.

\section{Significance of clay minerals occurrences}

The clay content has active effect on chemical, physical and morphological properties of soils as briefed afterhere:

1-The differences of clay mineral contents contribute to the quality of the soil, so soils that contain simple mineral suite, probably tend to need high levels of management.

2-The relative high clay content (particularly the smectite clay) improves to a great extent the soil water holding capacity and nutrients availability. Furthermore, the clay content gives the soils most of their cohesive and adhesive properties. However, the effect of relatively low clay content of the studied soils is very seemingly .

Egypt. J. Soil Sci. 55, No. 2 (2015) 
3-Soil swelling (by wetting) and shrinkage (by drying) are mainly clay mineral types and contents dependent.
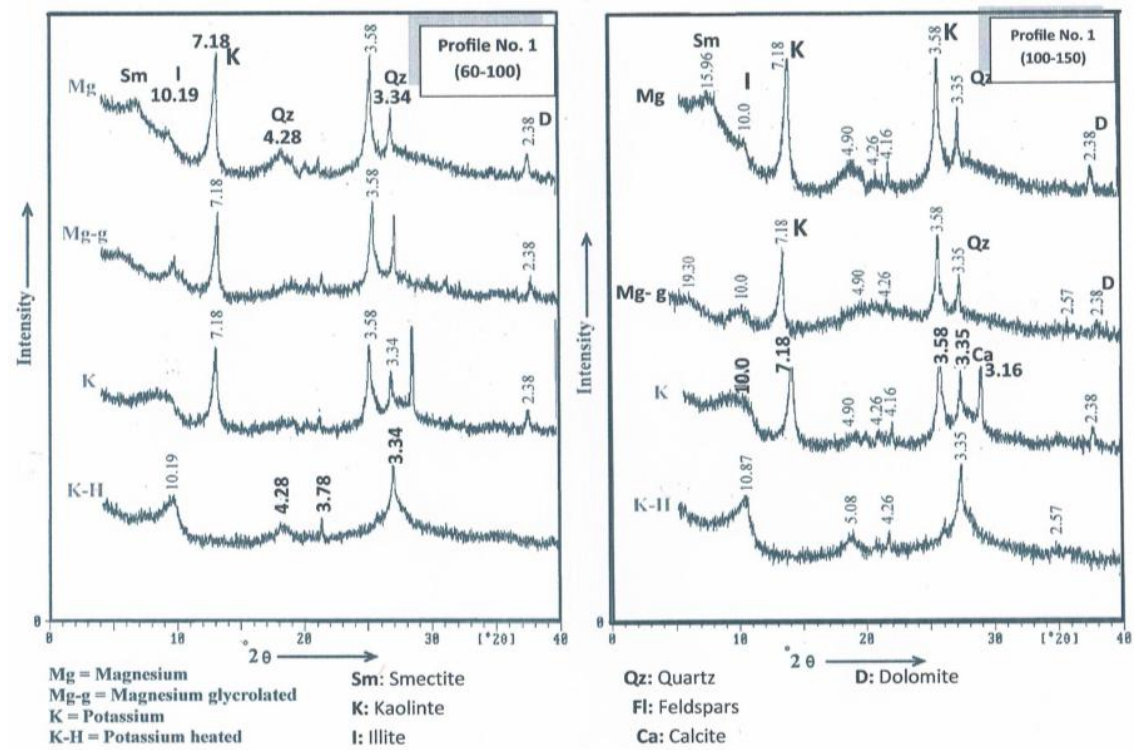

Fig. 5. X-ray differactograms of untreated and treated oriented clay fraction separated from profile No. 1.
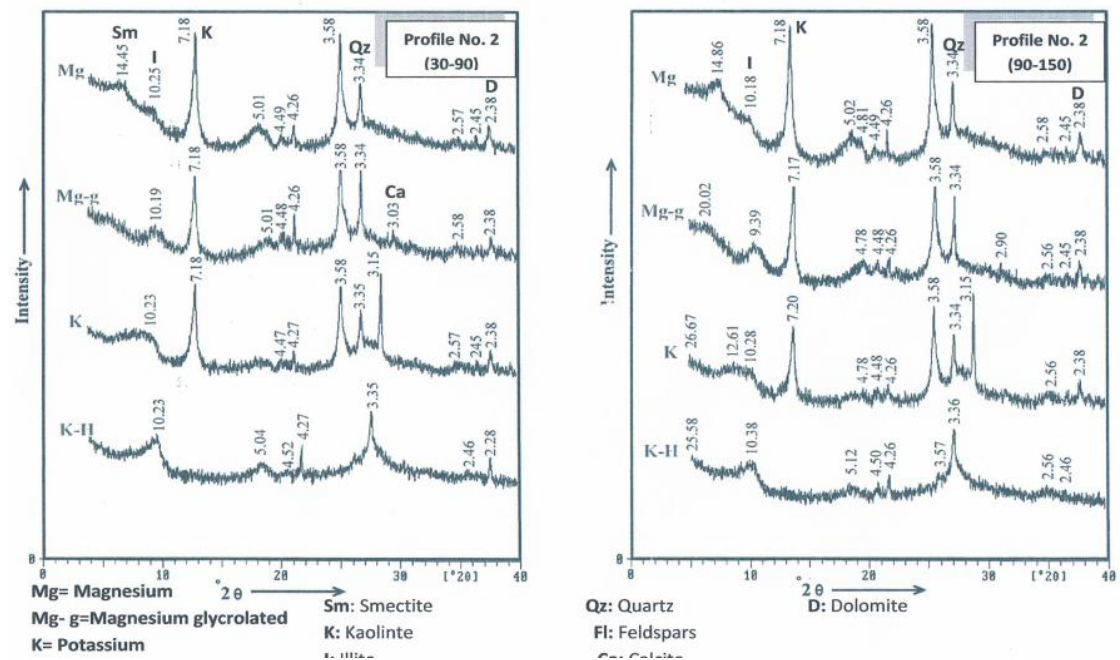

Fig. 6 . X-ray differactograms of untreated and treated oriented clay fraction separated from profile No. 2. 

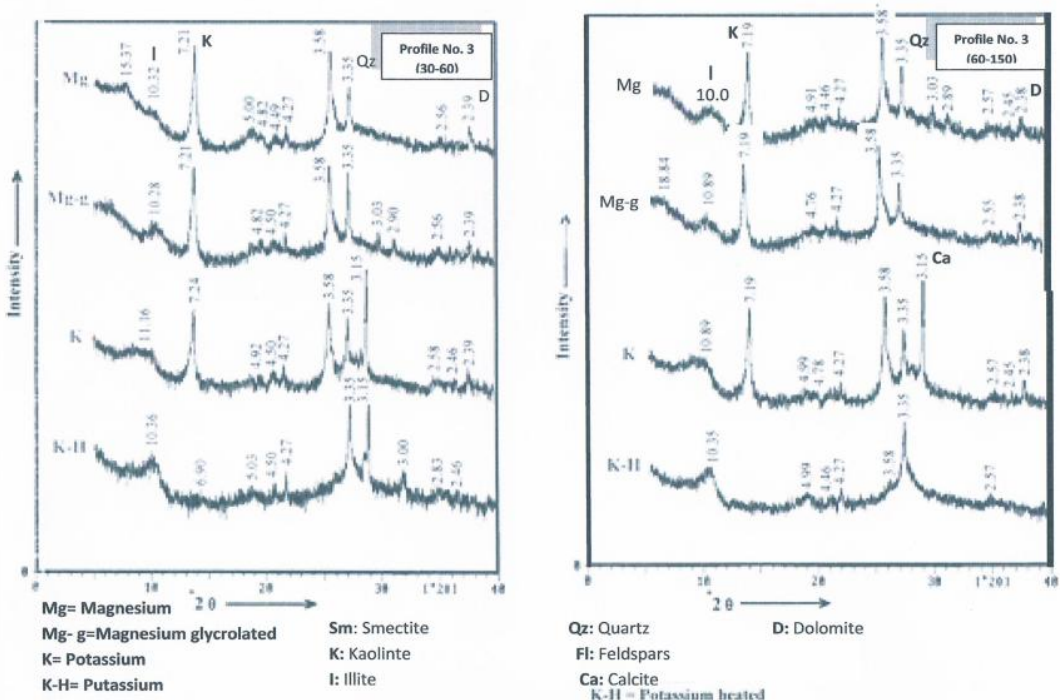

Fig. 7. X-ray differactograms of untreated and treated oriented clay fraction separated from profile No. 3 .
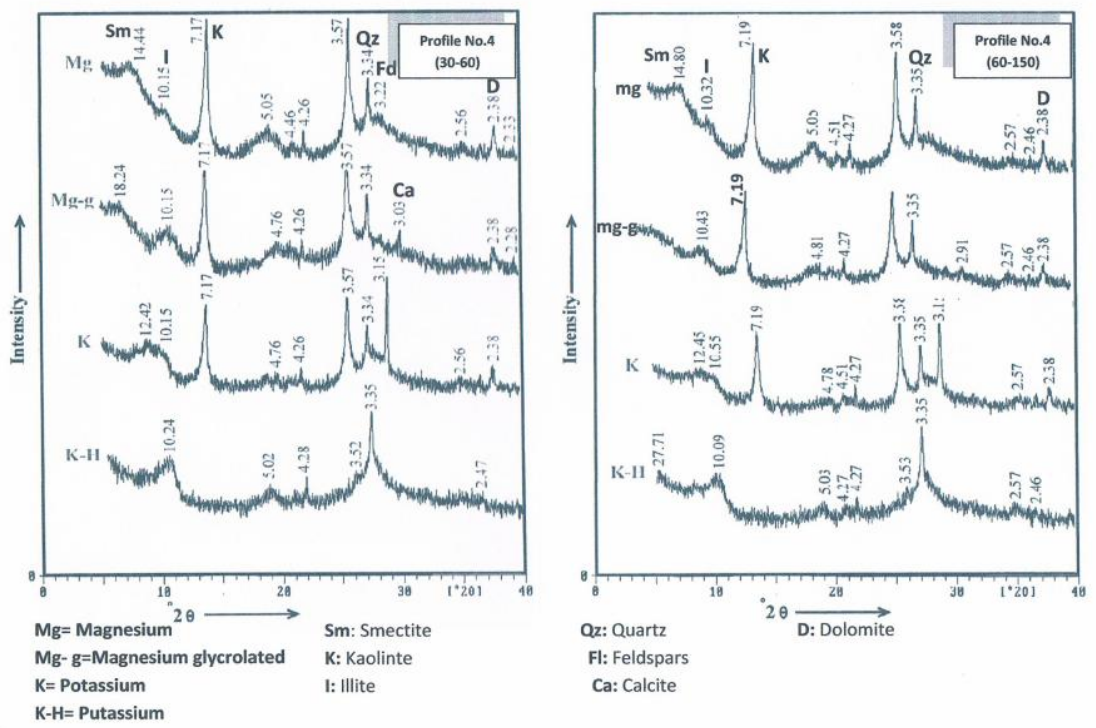

Fig. 8. X-ray differactograms of untreated and treated oriented clay fraction separated from profile No. 4. 

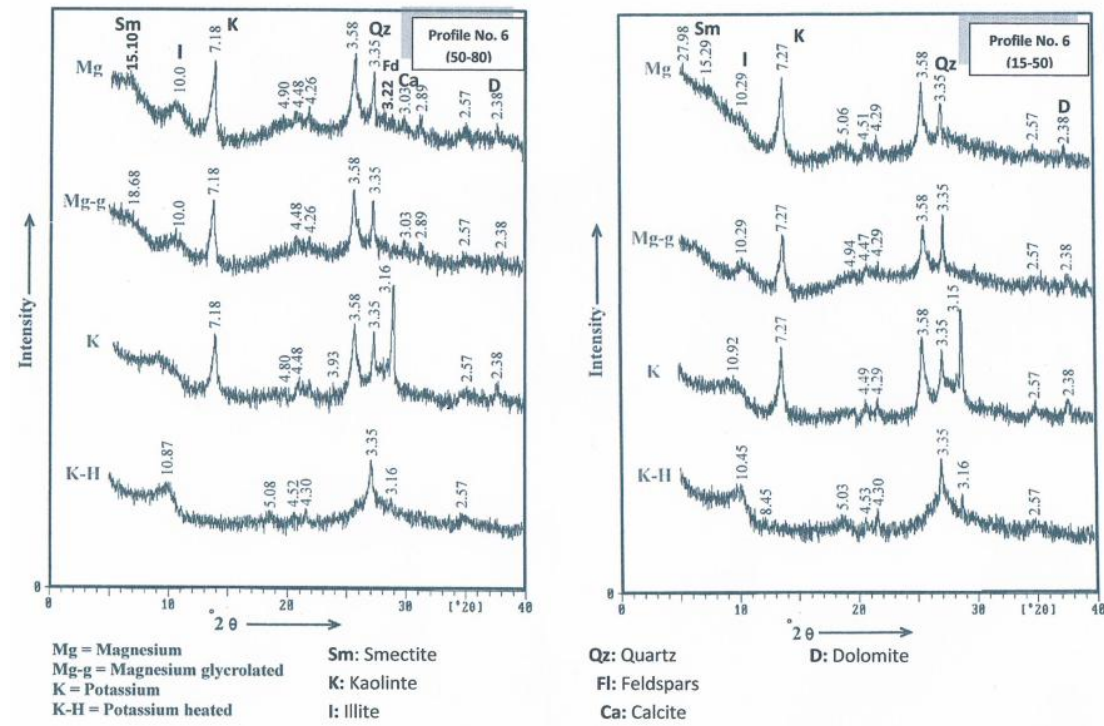

Fig. 9. X-ray differactograms of untreated and treated oriented clay fraction separated from profile No. 6.

\section{References}

Abo El-Ezz, M.S. (2000) "Land Forms of Egypt", 281 p. the Am. Univ., Cairo Press, Cairo, Egypt.

Barshad, I. (1964) Soil development. In Chemistry of the Soil (F.E. Bear Ed.) Reinhold Publ. Corp. , New York.,USA.

Biscays, P.E. (1965) Mineralogy and sedimentation of recent deep sea clays in the Atlantic Ocean and adjacent seas and oceans. Geol. Soc. Am. Bull. 76, 803-832.

Brewer, R. (1964) Fabric and Mineral Analysis. John Wiley and Sons, New York, USA $470 \mathrm{pp}$.

Brindly. G.W. and Brown, G. (1980) Clay structure of clay minerals and their identification. Min. Soc. Monograph. No. (5), London, UK. 495 pp.

Dixon, J.B. and Weed, S.B. (1977) Minerals in Soil Environments. Soil Sci., Soc. Am. Madison, Wisc., USA.

Dobos, E., Micheli, E., Baumgardner, M.F., Biehl, L. and Helt, T. (2002) Use of combined digital elevation model and satellite radiometric data for regional soil mapping. Geoderma, 97, 367- 391.

EGPC/CONCO-Coral (1987) Geologic map of Egypt, Scale 1:500000, Cairo, Egypt. 
El Sayed, A.E., Salem, S.M and Reinhard, O.G. (2013) Geology, morphotectonics and geophysical interpretation of Wadi Garara graben, East Aswan, Egypt, using landsat images. Australian Journal of Basic and Applied Sciences, 7(1), 263-277.

El-Kady, H.A. (1970) Pedological studies bearing on genesis and morphology of Maryut area . Ph.D Thesis, Fac. Agric. Ain Shams Univ., Egypt.

Folk, R. L. (1968) Petrology of Sedimentary Rocks; Sylabus, Univ., of Texas, USA, 170 $\mathrm{pp}$

Folk, R.L. (1980) Petrology of Sedimentary Rock; sylabus, Hamphill's Publishing Company, Austin, Texas. USA.

Gjems, O. (1967) Studies on clay minerals and clay mineral formation in soil profiles in Scondianvia. Jaurdunder Sokelsns Sertykk NR. 128, 305-407.

Greensmith, J.T., Ed. (1985) Petrology of the Sedimentary Rocks. $6^{\text {th }}$ edition, London,U.K.

Grim , R.E. (1968) Clay Mineralogy $2^{\text {nd }}$ ed. McGrow-Hill, New York, 560p.

Jackson, M.L. (1965) Clay transformations in soil genesis during the Quaternary. Soil Sci. 99, 15-22.

Jackson, M.L. (1969) Weathering of primary and secondary minerals in soils . Trans Ninth Int. Congr. Soil Sci., Adelaide, Australia, 4, 281-292.

Keer, P.F. (1959) Optical Mineralogy. McGraw-Hill book Company, Inc., New York, USA.

Keller, W.D. (1965) Clay minerals as influenced by environment of their formation. Bull. Am. Ass. Petr. Geol., 40, 2689-2710.

Keller, W.D. (1970) Environmental aspects of clay minerals. J. Sed. Petrol. 40, 788-854.

Kholief, M., Hilmy, E. M. and El Shahat, A. (1969) Geological and mineralogical studies of sand deposits in the Nile delta. J. Sediment. Petrol., 39, 1520.

Millot, G. (1970) Geology of Clay. Chapman and Hall. London,UK. 429p.

Milner, H.B. (1962) Sedimentary Petrology. George Allen and Unwin Ltd., Museum Street, London,U.K. V.1 and 11.

Mitchell, W.A. (1975) Soil Components. John, E., Gieseking, New York, USA. V2.

Pettijohn, F.J. (1975) Sedimentary Rocks. $3^{\text {rd }}$ edition, C.B.S. Publishery and Distributors, New Delhi, India.

Said, R. (2000) The Earth Science, 814 p. Hurbe and Raw Publishers, New York and London. 
Venkatarathnam, K., and Ryan, W.B.F. (1971) Dispersal pattern of clay minerals in the sediments of the Eastern Mediterranean Sea. Marine Geol., 11, 261-282.

Weaver, C.E. (1961) Clay mineralogy of late Cretaceous rocks in the Washaki Basin. Guide-book, Wyoming Geol. Ass. $16^{\text {th }}$ Ann. Conf., 148-154.

Weaver, C.E. (1989) Clays, Muds and Shales. Elsevier: 819p.

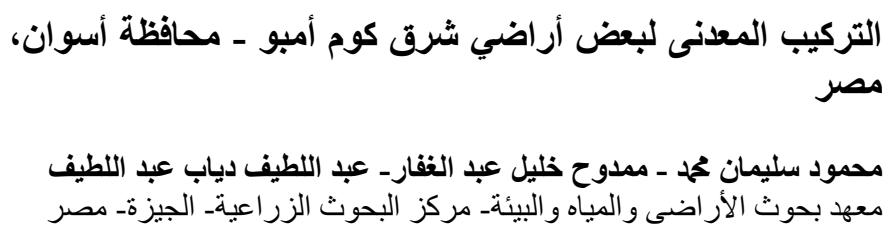

تقع منطقة الدراسة فى الجزء الجنوبى الثرقى لو ادى النيل بمحافظة أسوان،

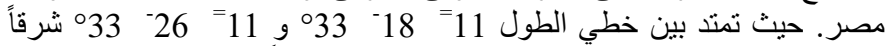

وخطي 30=

وتهدف هذه الدراسه الى التعرف على التركيب المعدني للتربه وكذللك أصل

ومدى تجانس هذه التربه في منطقة الدر اسه.

قبل البدء فى العمل الحقلى تم تجميع البيانات المتاحة عن منطقة الدراسة

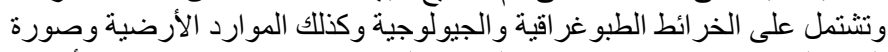

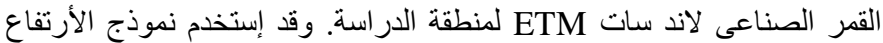

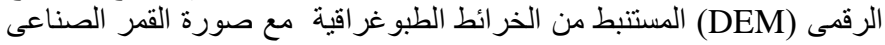

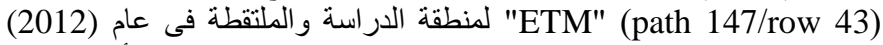

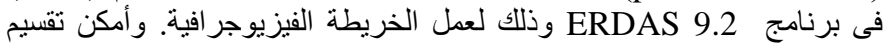

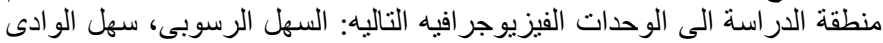

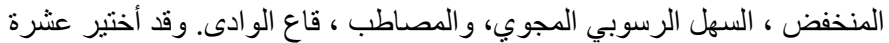

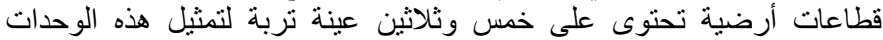
الفيزيوجر افية و اجري عليها التحليلات الطبيعية و المعدنية.

وتشير نتائج الدراسه الي أن التركيب المعدنى للرمل (0.125- 0.063مدم)

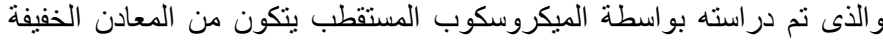

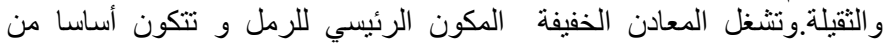

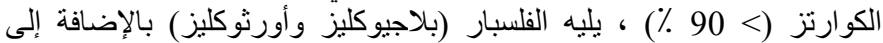

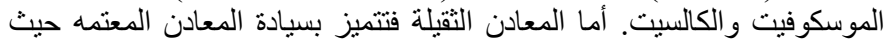

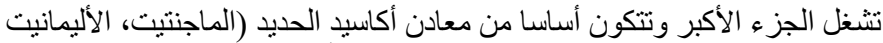

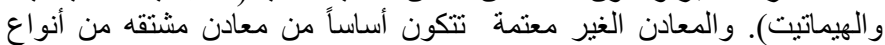
مختلفه من الصخور و وهي: و الصعادن الغير 
( أ ) المعادن النارية الأصل و هذه المعادن غير ثنابتة unstable وتشمل مجمو عة

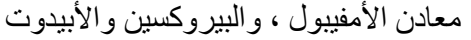

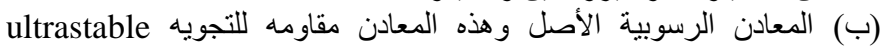
وتثمل الزركون ، التورمالين و الرونيل

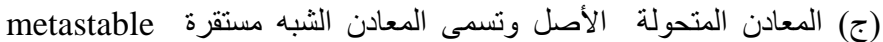
وتشمل معادن الجارنت، الكيانيت، الأشتيروليت، السليمانيت و الاندلوسيت.

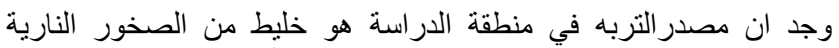

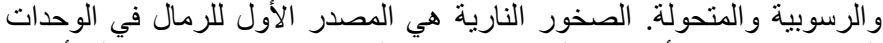

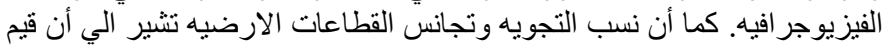

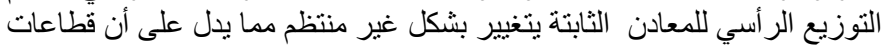

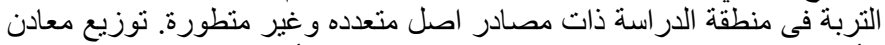

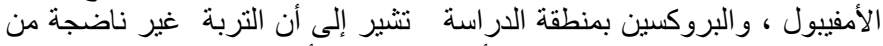

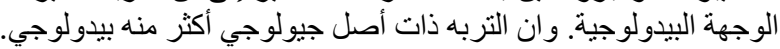

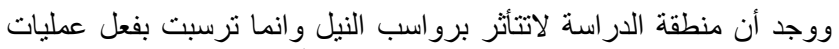

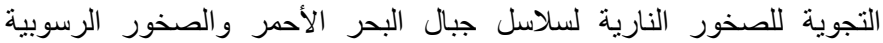

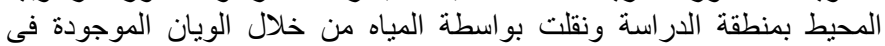

المنطقة.

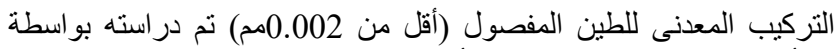

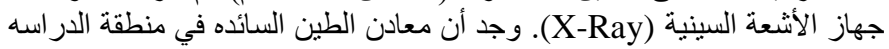

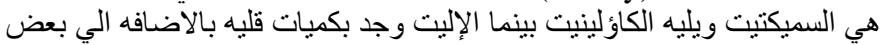

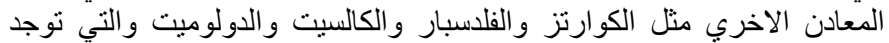

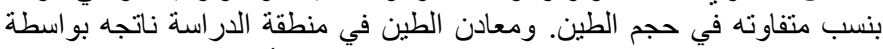

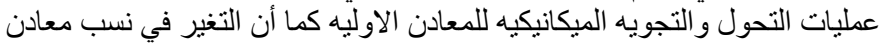

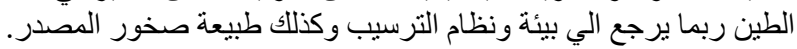

